\title{
Hymenoptera venom allergy and immunotherapy - what a General Practitioner should know
}

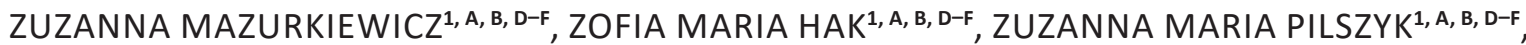 \\ $\begin{array}{lll}\text { ORCID ID: 0000-0002-7755-1607 } & \text { ORCID ID: 0000-0002-5574-4758 } & \text { ORCID ID: 0000-0001-5421-7166 }\end{array}$ \\ ALEKSANDRA ELŻBIETA PILSZYK ${ }^{2, A, ~ B, ~ D-F ~}$, KRZYSZTOF GOMUŁKA ${ }^{3, A, B, ~ D-F}$ \\ ORCID ID: 0000-0002-7250-4326 ORCID ID: 0000-0002-7218-2961
}

${ }^{1}$ Student Scientific Association of Adult Allergology, Wrocław Medical University, Wrocław, Poland

${ }^{2}$ Student Scientific Association at the Department of Obstetrics and Perinatology, Lublin Medical University, Lublin, Poland

${ }^{3}$ Department of Internal Medicine, Pneumology and Allergology, Wrocław Medical University, Wrocław, Poland

A - Study Design, B - Data Collection, C - Statistical Analysis, D - Data Interpretation, E - Manuscript Preparation, F - Literature Search, G - Funds Collection

Summary Due to the common prevalence of Hymenoptera, stings and bites are a well-known problem in society. Most often they are not life threatening, but for a group of people who are allergic to this venom, they are a significant problem. Although stinging species are widely known, patients often have a problem distinguishing between bee and wasp stings. Because of this, it is very important to educate people about Hymenoptera species, as well as about post-sting procedures. The consequences of exposure to venom can be serious, but there are solutions that can significantly affect the quality of life of people who are allergic to venom. One of these is equipping the patient with adrenaline auto-injectors, another is venom immunotherapy. In choosing the right method, it is crucial to gather a medical history and check if the patient meets certain guidelines. It is also important if there are other factors that are exceptions to the guidelines. Patients who are concerned with their reaction to Hymenoptera venom often turn to the General Practitioner first. This is why proper education and well-chosen medical treatment are so important at the primary care level. Providing relevant information and providing medical care can significantly increase the quality of life of patients.

Key words: Hymenoptera, immunotherapy, hypersensitivity, bees, wasps, primary health care.

Mazurkiewicz Z, Hak ZM, Pilszyk ZM, Pilszyk AE, Gomułka K. Hymenoptera venom allergy and immunotherapy - what a General Practitioner should know. Fam Med Prim Care Rev 2021; 23(1): 93-97, doi: https://doi.org/10.5114/fmpcr.2021.103162.

\section{Background}

Hymenoptera insects found in Poland which cause HVA (Hymenoptera Venom Allergy) include honeybees (Apis mellifera), European wasps (Vespula germanica), common wasps (Vespula vulgaris), hornets (Vespa sp.), umbrella wasps (Polistes sp.) and bumblebees (Bombus sp.) [1]. Allergic reactions to Hymenoptera venom vary from mild local reactions to severe systemic reactions, including anaphylaxis, which can lead to death [2]. Contact with venom is made by a sting in the case of a bee or by a bite in the case of a wasp. Furthermore, an allergic reaction may be caused by inhalation or swallowing the insect $[1,3]$.

The purpose of the article is to improve the quality of treatment and prevention of Hymenoptera venom allergy at the primary care level. Providing relevant information and proper medical care can significantly reduce the number of life-threatening incidents, such as anaphylaxis, as well as improving the quality of life of patients.

\section{Epidemiology}

The incidence of an extensive local reaction in the general population varies between $2.4 \%$ and $26.4 \%$ [4]. Generalised allergic reactions can occur at any age, typically among $5-8.9 \%$ of adults and $0.15-1.5 \%$ of children. The lower percentage amid children is associated with a lower sting/bite exposure [2]. The greater the exposure, the greater the incidence of Hymenoptera venom allergy [1]

Groups of people at increased risk of being stung/bitten include beekeepers and their families, greenhouse workers, peo- ple living near apiaries and courts, motorcyclists and cyclists, as well as professional groups such as bakers, confectioners, firefighters, farmers and gardeners [5].

\section{Prognostic factors and prevention}

Prognostic factors of severe systemic reaction include being over 45 years of age, cardiovascular diseases, coexistence of asthma, increased tryptase level in serum, taking medicines such as ACE (Angiotensin-converting-enzyme) inhibitors or $\beta$-blockers and the male gender $[1,6]$

Prevention of stings/bites consists of resigning from eating and drinking outside, walking barefoot, picking fruits, gardening and playing sports in fresh air. It is recommended to stay at a safe distance from hives and wasp nests. Wasp nests should not be removed on one's own [7].

\section{Wasp/bee differentiation}

To make the correct diagnosis, it is always worthwhile to ask the patient about the species of insect or to describe it as accurately as possible to determine the correct diagnosis. The nest can also tell us a lot about this. Honeybees mainly live in beehives but can also colonise cavities like hollow trees, wall voids or attics, where they are safe from the environment. Wasp nests are different. They do not have wax-producing glands and instead create nests from a paper-like substance from wood pulp. While honeybees can attack after being provoked, wasps are natural and more aggressive predators. Honeybees are also hairy, while wasps usually have a smooth and shiny exoskele- 
ton. You should ask the patient if the insect stung, because both honeybees and wasps are capable of this, but bees will die afterwards. If the string was not in the wound, we should also consider bumblebees and hornets. They are easily differentiated from each other, as they are much larger than wasps. Bumblebees are fuzzy and more peaceful than hornets [8]

\section{How to remove a sting}

Removing the sting is necessary to stop the patient's exposure to the allergen. Fast and correct action ensures reduction of the amount of venom pumped from the venom bag.

The sting should be lifted out with a stiff tool, e.g. by credit card, and removed with caution so as not to press the venom bag [2]. In most cases, the sting can be removed without medical help, with the exception being in the case of sting into the eyeball or conjunctiva [9].

\section{Immunotherapy (What insects do we have therapy for?)}

Immunotherapy for bee and vespid venom is available [10]. Patients with both bee and venom hypersensitivity can be treated with combined immunotherapy, which is considered to be safe [11]. It has been shown that Hymenoptera venom immunotherapy improves the quality of life of the patients [12].

\section{Immunotherapy qualification}

Qualification to Hymenoptera venom immunotherapy consists of clinical and immunological criteria. A scale proposed by Mueller et al. is used to determine the severity of an allergic reaction to a sting/bite. The scale has degrees from $0^{\circ}$ to $\mathrm{IV}^{\circ}$ :

$0^{\circ}$ - large local reaction (oedema larger than $10 \mathrm{~cm}$, lasting longer than 24 hours):

- $1^{\circ}$ - urticaria, itch;

- $\quad \mathrm{I}^{\circ}$ - any symptom mentioned above and at least two of the following: Quincke's oedema (as a single symptom, it qualifies as $\|^{\circ}$ ), tightness of the chest, nausea, vomiting, diarrhoea, colic pain in the abdomen, dizziness;

- $\quad \quad \mathrm{III}^{\circ}$ - any symptom mentioned above and at least two of the following: dyspnoea, wheezing, laryngeal whiz (all three symptoms as a single one qualifies as $1 \mathrm{II}^{\circ}$ ), dysphagia, weakness, sense of danger to life, anxiety;

- $\quad \mathrm{IV}^{\circ}$ - any symptom mentioned above and at least two of the following: hypotension, fainting, loss of consciousness, urinary and stool incontinence, cyanosis.

$\mathrm{III}^{\circ}$ and $\mathrm{IV}^{\circ}$ systemic reactions to Hymenoptera venom with cardiovascular symptoms and/or respiratory reactions (e.g. laryngeal oedema, bronchospasm), despite the age of the patient, are absolute indications to immunotherapy. $1^{\circ}$ and $\|^{\circ}$ reactions are relative indications if they were accompanied by special circumstances. Local reactions, especially occurring several times (possibly strong local reactions in people with a high risk of being stung/bit) and atypical symptoms are not indications to immunotherapy.

Confirmation of the presence of IgE antibodies directed against venom allergens is an immunological criterion. In order to confirm this, diagnostic tests, such as skin prick tests and/or intradermal tests, evaluation of IgE anti-venom antibodies levels in the serum, evaluation of IgE antibodies directed against individual venom components, must be done. If the results of skin and serological tests are negative, cellular tests, such as a basophil activation test (BAT) and cellular allergen stimulation test (CAST), can be done.

Tryptase levels should be determined for each patient qualified for Hymenoptera venom immunotherapy. An elevated level $(>11.4 \mathrm{ng} / \mathrm{ml}$ ) may be evidence of mastocytosis. Mastocytosis can occur with normal tryptase levels as well. An elevated tryptase level means a risk of complications and poorer immunotherapy effectiveness. However, this is not a contraindication to immunotherapy [10].

\section{Immunotherapy and age}

Venom immunotherapy is absolutely contraindicated among children under 2 years of age. The age between 2 and 5 years is a relative contraindication. Venom immunotherapy is allowed if a child has $\mathrm{III}^{\circ}$ and $\mathrm{IV}^{\circ}$ systemic reactions with cardiovascular symptoms and/or respiratory system reactions [10]. The child must be willing to cooperate.

Hymenoptera venom immunotherapy, as opposed to immunotherapy for inhaled allergens, is commonly used among elderly patients. There is no upper age limit for venom immunotherapy.

\section{Derogations from guidelines}

Despite the guidelines presented above, there are situations when it is possible to admit a patient to VIT when only $\mathrm{I}^{\circ}$ and $1{ }^{\circ}$ systemic reactions to Hymenoptera venom are met. Before making a decision about immunotherapy, aspects such as the risk of another sting, the availability of medical assistance or the patient's mental state should be taken into consideration [4].

The anxiety of insect stings is a significant problem for patients. Research conducted by Oude Elberink et al. shows that people exposed to severe reactions to stings suffer from emotional stress and have to keep constant vigilance associated with the possibility of being stung, which significantly reduce the quality of life [13]. The use of VIT has a significant impact on the psychological comfort of this group of patients according to studies carried out by Oude Elberink et al. $91.5 \%$ of people are satisfied with the therapy, and $85 \%$ would choose it again [14]. In addition, patients reported that VIT significantly reduces the level of anxiety and depression [15].

Large exposure to Hymenoptera venom is of particular concern for beekeepers, their families and people living around the apiary. In these groups of people, desensitisation therapy is recommended, even if the only allergic systemic reactions that occur are urticaria or angioedema. The significant risk of subsequent stings is an additional aspect that supports the qualification of the patient for desensitisation therapy, even when Hymenoptera venom does not cause a life-threatening reaction $[4,10]$.

\section{Contraindications for wasp and bee venom immunotherapy}

Absolute contraindications for the use of venom immunotherapy include: AIDS (Acquired Immunodeficiency Syndrome), pregnancy, uncontrolled asthma, active phase of autoimmune disease, cancer and being under 2 years of age. It should be noted that of the above-mentioned conditions, only AIDS permanently excludes the start of VIT, while the rest are temporary.

According to the latest recommendations, relative contraindications include: multi-organ autoimmune diseases, partially controlled asthma, stable cancer and remission, being under 5 years of age, cognitive and mental disorders, chronic infections, immunodeficiencies, HIV (Human Immunodeficiency Virus) infection in stage $A$ and $B$ and immunosuppressive treatment [16].

\section{ACE inhibitors and $\beta$-blockers}

ACE (angiotensin-converting-enzyme) inhibitors and $\beta$-blockers are drugs used, among others, in hypertension treatment [17]. $31.5 \%$ of the adult population in Poland suffers from hypertension [18], and it is the most common chronic disease in the family doctor practice [19]. 
$\beta$-blockers cause negative chronotropic, inotropic, bathmotropic and dromotropic effects by blocking $\beta$ adrenergic receptors. ACE inhibitors inhibit angiotensin I to angiotensin II conversion and bradykinin degradation, which leads to vasodilation and, as a consequence, to blood pressure reduction. Adrenaline, on the other hand, stimulates $\alpha$ and $\beta$ adrenergic receptors and is used in the treatment of anaphylaxis. Stimulation of $\alpha$ and $\beta$ receptors causes a spasm of smooth muscles in the vessels, and this leads to an increase in blood pressure $\left(\alpha_{1}\right.$ receptors stimulation effect) and heart rate ( $\beta_{1}$ receptors stimulation effect). Therefore, ACE inhibitors and $\beta$-blockers have an antagonistic effect on adrenaline, and this is why there is a risk associated with taking these drugs during Hymenoptera venom immunotherapy. Side effects, such as anaphylactic shock, may occur during immunotherapy [17].

The opinions of experts from the EAACI (European Academy of Allergology and Clinical Immunology) and the AAAA (American Academy of Allergology, Asthma and Immunology) are divergent [20]. These drugs potentially increase the risk of complications during immunotherapy; however, they are not a contraindication to it [21]. It is believed that the overall risk of death for patients treated for cardiovascular disease who are at risk for systemic reaction is considered to be greater without venom immunotherapy than during it, regardless of taking $\beta$-blockers [22]. It has been proven that immunotherapy while taking ACE inhibitors and $\beta$-blockers is safe [21].

Discontinuation of taking ACE inhibitors and $\beta$-blockers is recommended if their intake is not necessary or the replacement with another group of drugs is possible. It is not recommended to stop taking drugs when a patient needs to be treated with them and with no possibility of drug replacement [10]. It should be noted that these recommendations also apply to other groups of drugs, such as $\alpha$-blockers, MAO (monoamine oxidase) inhibitors and renin inhibitors [22]. Patients should be informed about the risk [10]. Complications include increased risk of systemic reactions and less effective adrenaline treatment in case of anaphylaxis [4].

\section{Technique of venom immunotherapy}

A patient who has been qualified for treatment must undergo a series of basic tests, such as ECG, chest x-ray, laboratory tests of inflammation parameters (morphology, CRP), as well as a subjective and physical examination, in order to accurately assess his health.

The initial phase of immunotherapy begins with a dose of $1 \mu \mathrm{g}$ of venom. Initial doses are determined on an individual basis and for patients with high clinical reactivity. The starting dose may be $0.001-0.1 \mu \mathrm{g}$ of venom. During this phase, vaccine doses are gradually increased. The target value is $100 \mu \mathrm{g}$ venom, which is also the standard maintenance dose [10].

The induction phase depends on the type of protocol and can last from 3-5 hours (ultra-rush), 2-3 days (rush), 6-8 weeks (cluster) and 16-20 weeks (conventional immunotherapy). In the case of the ultra-rush and rush protocol, the induction phase is performed in a hospital, as it carries the risk of major complications. The patient achieves clinical tolerance when the maintenance dose is reached. If VIT is ineffective, consideration should be given to increasing the dose to $200 \mu \mathrm{g}$ of venom. This proceeding provides a higher level of immune protection. Therapy should be continued for 3 to 5 years to achieve long-term effectiveness. The optimal duration of VIT is 5 years, but it was proven that longer treatment is more effective [10, 23, 24].

\section{Effectiveness}

There is little data on long-term venom immunotherapy. It is important that future research investigates the effectiveness of VIT.

Based on current knowledge, it can be concluded that venom immunotherapy is more effective in children than adults.
According to Bilò et al., after 20 years of therapy, failure of VIT in only $5 \%$ of children was confirmed [25]. In addition, long-term wasp venom therapy is more effective than bee venom therapy. 7-10 years after termination of therapy, failure was noted in $16.2 \%$ of patients desensitised with bee venom, and this occurred in only $10.2 \%$ of patients treated with wasp venom [10].

Bilò and al. showed that among patients who had earlier experienced a large local reaction by re-stinging/biting, 24\% had no allergic reaction, $52 \%$ had a large local reaction again, and $24 \%$ had a systemic reaction. Risk of systemic reaction was higher in patients with positive skin prick tests to honeybee or vespid venom. This research may be the basis for future diagnostics of the risk of severe systemic reactions [6].

\section{How many adrenaline auto-injectors should be prescribed and to whom? Large local reaction and anaphylaxis management}

In case of a generalised anaphylaxis, there are adrenaline auto-injectors designed to deliver a single dose of 0.15 or 0.3 $\mathrm{mg}$ adrenaline in a sterile solution. It should be applied intramuscularly to the lateral side of the thigh [25].

If the patient has had any cardiac and/or respiratory symp-

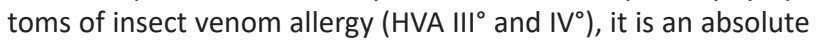
requirement to have two packs of adrenaline for self-injection during venom immunotherapy. However, if the patient has systemic symptoms with coexisting mastocytosis, has higher tryptase levels or has had respiratory and/or systemic symptoms with risk factors for failure, he should be advised to have prefilled syringes even after the end of immunotherapy $[10,26]$.

Patients during VIT with mild systemic symptoms (HVA I and $\mathrm{I}^{\circ}$ ), but with a high possibility of being stung, may be prescribed adrenaline, though this is a relative recommendation. The same situation occurs when these patients are after the treatment; however, its effectiveness has not been confirmed [10].

The spectrum of symptoms that occur in an allergic person after contact with Hymenoptera venom also includes the appearance of a local reaction. An LLR (large local reaction) is described when the diameter of erythema and oedema is over $10 \mathrm{~cm}$, and the symptoms may persist for more than 24 hours. In such a situation, the sting should be removed, and antihistamines and glucocorticosteroids should be taken. The use of auto-injection adrenaline is not recommended if there is no dyspnoea, wheezing, difficulty swallowing, significant weakness or systemic symptoms [1].

In the case of an LLR in the mouth and throat area, there is a greater risk of airway obstruction. The patient should be referred to hospital for observation. Adrenaline is used for treatment, as well as antihistamines and glucocorticosteroids, administered intravenously, not orally [27].

\section{Other than anaphylaxis, severe sting/bite reactions}

Despite anaphylactic shock, Hymenoptera venom can cause a number of rare and unusual symptoms. They can be local or systemic and vary in the time from the sting to the onset of symptoms $[10,28]$.

By analysing rare severe sting reactions, they can be classified by their affected systems or organs.

Nervous system disorders usually affect adults. These may include peripheral neuritis, acute disseminated encephalomyelitis, Guillain-Barré syndrome, seizure, psychosis and - in the case of multiple stings - stroke. Symptoms of the cardiovascular system include cardiomyopathy, arrhythmias and silent myocardial infarction [28].

Consequences of an eye sting can vary widely. They range from mild conjunctivitis, uveitis and keratitis to sudden loss of vision. Corneal damage due to stings can cause severe inflammation, lens abscess, cataract and optic nerve damage [10, 28]. 
Muscles can also be affected by an allergy to Hymenoptera venom. A dangerous manifestation after single or multiple $\mathrm{Hy}$ menoptera stings is rhabdomyolysis, which results in an acute increase of creatinine in blood. This can result in acute kidney damage. A similar effect can also cause internal haemorrhaging, which is also one of the unusual symptoms of hypersensitivity to venom. A haemorrhage may occur in the lungs or spleen [28].

It is worth mentioning that a sting/bite on the head or neck area is not a risk factor for IV ${ }^{\circ}$ systemic reaction among patients with Hymenoptera venom allergy [29].

\section{Conclusions}

In conclusion, if a patient with a reaction to the sting or bite comes to the General Practitioner, a thorough medical interview should be collected. Depending on the obtained information, appropriate actions should be taken.

Treatment procedures are as follows: If a patient presents a large local reaction covering an area of the body which does not include the mouth or throat region, cold compresses, antihistamines or glucocorticosteroids should be prescribed. If local reactions occur in the mouth and throat area, hospitalisation, intramuscular adrenaline, intravenous antihistamines or corticosteroids should be considered in addition to observation. In case of anaphylaxis, follow the guidelines for treatment of this condition.

In case of large local reaction or systemic reaction, a thorough interview should be conducted to determine whether the patient qualifies for Hymenoptera venom immunotherapy.

Correct assessment of candidates for Hymenoptera venom immunotherapy is very important. It should be judged whether after sting/bite there was a local or systemic reaction. In case of a systemic reaction, its degree should be assessed using the scale proposed by Mueller et $\mathrm{al}^{\mathrm{III}} \mathrm{I}^{\circ}$ and IV ${ }^{\circ}$ systemic reactions are absolute indications to immunotherapy. $1^{\circ}$ and $11^{\circ}$ systemic reactions and large local reactions are relative indications if they are accompanied by special circumstances, such as being a beekeeper or beekeeper's family member, poor access to medical care, patient's hightened anxiety level or high risk of re-stinging/ /re-biting. If there are no special circumstances, there is no indication for Hymenoptera venom immunotherapy. Potential candidates who meet the criteria should be referred to an allergy clinic for qualifying diagnosis.

Every General Practitioner should remember to prescribe adrenaline for every patient with a life endangering Hymenoptera venom allergy and patients during venom immunotherapy.

Abbreviations. ACE - angiotensin-converting-enzyme; HVA - Hymenoptera venom allergy; LLR - large local reaction; VIT - venom immunotherapy.

Source of funding: This work was funded from the authors' own resources.

Conflicts of interest: The authors declare no conflicts of interest.

\section{References}

1. Nittner-Marszalska M. Alergia na owady. In: Pawliczak R. ed. Alergologia - kompendium. 2nd ed. Poznań: Termedia; 2018: 235-242 (in Polish).

2. Stobiecki M. Alergia na jad owadów błonkoskrzydłych. In: Obtułowicz K. ed. Alergologia. Warszawa: Wydawnictwo Lekarski PZWL; 2016: 366-375.

3. Pali-Schöll I, Blank S, Verhoeckx K, et al. EAACl position paper: comparing insect hypersensitivity induced by bite, sting, inhalation and ingestion in human beings and animals. Allergy 2019; 74(5): 874-887.

4. Sturm GJ, Varga E-M, Roberts G, et al. EAACl guidelines on allergen immunotherapy: Hymenoptera venom allergy. Allergy 2018; 73(4): 744-764.

5. Matysiak J, Kokot ZJ, Matysiak J. Alergia na jad pszczeli u pszczelarzy. Alerg Astma Immun 2017; 22(1): 5-11 (in Polish).

6. Bilò MB, Martini M, Pravettoni V, et al. Large local reactions to Hymenoptera stings: outcome of re-stings in real life. Allergy 2019; 74(10): 1969-1976.

7. Bonifazi F, Jutel M, Biló BM, et al. Prevention and treatment of hymenoptera venom allergy: guidelines for clinical practice. Allergy 2005; 60(12): 1459-1470.

8. Grabowski M, Jaskuła R, Pabis K. Ilustrowana encyklopedia owadów i pajęczaków Polski. Warszawa: Carta Blanca; 2012 (in Polish).

9. Zając A, Palka-Błaszczak J. Usuwanie żq̨dła owada. In: Pietrzyk JJ, Szajewska H, Mrukowicz J. eds. ABC zabiegów w pediatrii. Podręcznik dla studentów medycyny, pielęgniarek i lekarzy. Kraków: Medycyna Praktyczna; 2010: 373 (in Polish).

10. Nittner-Marszalska M. Immunoterapia w alergii na jad owadów błonkoskrzydłych. Alergol Pol Pol J Allergol 2018; 5(2): 85-93 (in Polish).

11. Čerpes U, Arzt-Gradwohl L, Schrautzer C, et al. Simultaneous up-dosing of bee and vespid venom immunotherapy is safe. Allergy 2020; 75(3): 721-723.

12. Cichocka-Jarosz E. Wpływ immunoterapii alergenowej na jakość życia chorych na astmę, alergiczny nieżyt nosa i alergię na jad owadów. Alergol Pol Pol J Allergol 2018; 5(3): 148-156 (in Polish).

13. Oude Elberink JNG, Monchy JGR de, Golden DBK, et al. Development and validation of a health-related quality-of-life questionnaire in patients with yellow jacket allergy. J Allergy Clin Immunol 2002; 109(1): 162-170.

14. Oude Elberink JNG, Heide $\mathrm{S}$ van der, Guyatt GH, et al. Analysis of the burden of treatment in patients receiving an EpiPen for yellow jacket anaphylaxis. J Allergy Clin Immunol 2006; 118(3): 699-704.

15. Findeis $\mathrm{S}$, Craig T. The relationship between insect sting allergy treatment and patient anxiety and depression. Allergy Asthma Proc 2014; 35(3): 260-264.

16. Pitsios C, Demoly P, Bilò MB, et al. Clinical contraindications to allergen immunotherapy: an EAACl position paper. Allergy 2015; 70(8): 897-909.

17. Korbut R. Farmakologia. 2nd ed. Warszawa: Wydawnictwo Lekarskie PZWL; 2017 (in Polish).

18. Narodowy Fundusz Zdrowia. NFZ o zdrowiu. Nadciśnienie tętnicze. Warszawa: Centrala Narodowego Funduszu Zdrowia Departament Analiz i Strategii; 2019 (in Polish).

19. Bujnowska-Fedak MM, Sapilak BJ, Steciwko A. Epidemiologia schorzeń i struktura zachorowań w praktyce lekarza rodzinnego. Fam Med Prim Care Rev 2011; 13(2): 135-139 (in Polish).

20. Golden DBK, Demain J, Freeman T, et al. Stinging insect hypersensitivity: a practice parameter update 2016. Ann Allergy Asthma Immunol 2017; 118(1): 28-54.

21. Stoevesandt J, Hosp C, Kerstan A, et al. Hymenoptera venom immunotherapy while maintaining cardiovascular medication: safe and effective. Ann Allergy Asthma Immunol 2015; 114(5): 411-416.

22. Kempiński K, Niedoszytko M. The effectiveness of immunotherapy in hymenoptera venom allergy. Alerg Astma Immun 2011; 16(3): $124-131$ 
23. Nittner-Marszalska M. Alergia na owady. 2nd ed. Łódź: Wydawnictwo Mediton; 2016 (in Polish).

24. Golden DBK, Kwiterovich KA, Kagey-Sobotka A, et al. Discontinuing venom immunotherapy: extended observations. J Allergy Clin Immunol 1998; 101(3): 298-305.

25. Bilò MB, Cichocka-Jarosz E, Pumphrey R, et al. Self-medication of anaphylactic reactions due to Hymenoptera stings-an EAACl Task Force Consensus Statement. Allergy 2016; 71(7): 931-943.

26. Bilò MB, Tontini C, Martini M, et al. Clinical aspects of hymenoptera venom allergy and venom immunotherapy. Eur Ann Allergy Clin Immunol 2019; 51(6): 244-257.

27. Jutel M, Cichocka-Jarosz E, Użq̨dlenie przez owady. In: Gajewski P, eds. Interna Szczeklika - mały podręcznik 2019/2020. 11th ed. Kraków: Medycyna Praktyczna; 2019: 1489-1491 (in Polish).

28. Mingomataj EC, Bakiri AH, Ibranji A, et al. Unusual reactions to Hymenoptera Stings: what should we keep in mind? Clin Rev Allergy Immunol 2014; 47(1): 91-99.

29. Cichocka-Jarosz E, Nittner-Marszalska M, Mól N, et al. Hymenoptera Sting in the head and neck region is not a risk factor for grade IV systemic reactions in patients with venom allergy. Pol Arch Intern Med 2019; 129(3): 160-166.

Tables: 0

Figures: 0

References: 29

Received: 25.05.2020

Reviewed: 25.06.2020

Accepted: 31.10 .2020

Address for correspondence:

Krzysztof Gomułka, MD, PhD

Katedra i Klinika Chorób Wewnętrznych, Pneumonologii i Alergologii

Uniwersytet Medyczny we Wrocławiu

ul. Marii Skłodowskiej-Curie 66

50-369 Wrocław

Polska

Tel.: +48 71 784-26-47

E-mail: krzysztof.gomulka@umed.wroc.pl 